\title{
KATEKESE PENDALAMAN KITAB SUCI UNTUK MENINGKATKAN RASA PERCAYA DIRI DAN KEBERANIAN MENGUNGKAPKAN PENGALAMAN IMAN BAGI ANAK BINAAN EMAUS DALAM RANGKA BULAN KITAB SUCI NASIONAL TAHUN 2020
}

\author{
Ason $^{1}$, Septian Peterianus ${ }^{2}$ \\ ${ }^{1,2}$ Dosen STKIP Melawi \\ Jl. RSUD Melawi km. 04 Kec.Nanga Pinoh Kab. Melawi Kalimantan Barat \\ 1asonyakobus@gmail.com, ${ }^{2}$ speterianus@gmail.com
}

\begin{abstract}
The purpose of this service activity is to introduce the holy book as a source of faith and inspiration for life. Specifically, the aim of this activity is to increase the confidence and courage of the boarders who are assisted by Emmaus in sharing their faith experiences based on the scriptures. The method used in deepening the scriptures is the catechetical method of the people. Indepth meetings are held 1 (once) a week for 4 (four) weeks in September 2020. Each meeting has a sub-theme as an elaboration of the big theme, namely: "Proclaiming the Good News Amida Crisis of Faith and Identity." The data collection technique used is direct observation in which the abserver is involved in the activity. The object observed was the participants' self-confidence and courage in the deepening of diabetes. The result that was achieved in this service activity was an increase in the sense of self-confidence and the courage of the participants in thanks to the technique. This is indicated by the increase in the percentage of the active study participants who express their experiences of faith based on the scriptures.
\end{abstract}

Key words: Catechesis, deepening of the scriptures, Emmaus-assisted boarders

\begin{abstract}
Abstrak: Tujuan kegiatan pengabdian ini adalah mengenalkan kitab suci sebagai sumber iman dan inspirasi hidup. Secara khusus tujuan kegiatan ini meningkatkan rasa percaya diri dan keberanian anak asrama binaan Emaus dalam berketekese, mengungkapkan pengalaman iman mereka berdasarkan kitab suci. Metode yang digunakan dalam pendalaman kitab suci adalah metode katekese umat. Pertemuan pendalaman dilaksanakan 1 (satu) kali seminggu selama 4 (empat) minggu dalam bulan September 2020. Setiap pertemuan memiliki sub tema sebagai penjabaran dari tema besar yakni;"Mewartakan Kabar Baik Di Tengah Krisis Iman dan Identitas." Teknik pengumpulan data yang digunakan adalah observasi langsung di mana abserver terlibat didalam kegiatan. Obyek yang diobservasi adalah rasa percaya diri dan keberanian peserta pendalaman dalam berkatekese. Hasil yang dicapai dalam kegiatan pengabdian ini adalah rasa percara diri dan keberanian peserta dalam berkatekese meningkat. Hal ini ditunjukkan dengan bertambahnya presentase jumlah peserta pendalaman yang aktif berkatekese mengungkapkan pengalaman imannya berdasarkan kitab suci.
\end{abstract}

Kata kunci: Katekese, pendalaman kitab suci, anak asrama binaan Emaus 
$\mathrm{B}$ ulan September adalah bulan yang ditetapkan oleh Gereja Katoliksebagai Bulan Kitab Suci Nasional(BKSN). Ha ini dimaksudkan agar umat katolik semakin mendekatkan diri dengan kitab suci (Jakarta, CNN Indonesia).BKSN umumnya diisi dengan beragam kegiatan, baik dalam lingkup kring, lingkungan, wilayah, paroki, biara, atau komunitas. Kegiatan umumnya meliputi renungan bersama, pendalaman kitab suci, lomba membaca kitab suci, cerdas cermat kitab suci dan pameran buku.

Dilihat dari sejarahnya cikal bakal BKSN berawal ketika Konsili Vatikan II (19621965). Dei Verbum, salah satu dokumen yang dihasilkan, berbicara tentang kitab suci. Para bapa Konsili menganjurkan jalan masuk menuju kitab suci agar dibuka selebarlebarnya untuk kaum beriman. Dari sana, muncullah ajakan untuk tekun membaca kitab suci. Sejak saat itu pula jalan masuk menuju kitab suci pun dibuka dengan menerjemahkan kitab suci dalam bahasa setempat.

Di Indonesia, Gereja Katolik bekerja sama dengan Lembaga Alkitab Indonesia (LBI) untuk menerjemahkan kitab suci yang kini diakui Gereja Katolik maupun Protestan. Namun,meski sudah diterjemahkan ke dalam bahasa Indonesia, umat belum mulai membacakitab suci. Lembaga Biblika Indonesia, salah satu lembaga milik Konferensi Waligereja Indonesia (KWI). Denan mengerahkan sejumlah usaha KWI berusaha agar umat mulai membaca kitab suci. Usaha ini dimulai dengan gagasan Hari Minggu Kitab Suci (HMKS) secara nasional, di mana setiap minggu tertentu, Keuskupan dan Paroki didorong untuk menggelar ibadah khusus serta kegiatan seputar kitab suci

Berbagai upaya telah dilakukan Gereja Katolik dalam rangka mengenalkan kitab suci kepada umat, namun upaya tersebut masih belum bisa menghasilkan buah melimpah. Pada sidang KWI tahun 1977, para uskup menetapkan minggu pertema dalam bulan September sebagai Hari Minggu Kitab Suci (HMKS). Dalam perkembangannya satu hari minggu atau satu minggu dirasa tidak cukup untuk mendalami kitab suci sehingga pada akhirnya sepanjang bulan September dijadikan Bulan Kitab Suci Nasional.

Pada bulan Kitab Suci Nasional Tahun 2020 mengambil tema:” Mewartakan Kabar Baik Di Tengah Krisis Iman dan Identitas.” Tema ini mengangkat pengalaman Bangsa Israel yang mengalami krisis iman dan identitas ketika mereka berada di tempat pembuangan (Babel). Mereka mengalami kriris iman kepada Yahwe (Allah), dan mereka juga mengalami krisis identitas sebagai bangsa pilihan. Gereja Katolik secara nasional mengangkat masalah krisis iman dan identitas karena Gereja Ketolik meliahat dan 
mengalami bahwa generasi muda katolik saat ini mengalami hal yang sama dengan bangsa Israel, yakni mengalami krisi iman dan identitas.

Dengan perkembangan ilmu pengatahuan dan teknologi yang semakin pesat dan canggih dewasa ini disatu sisi sangat membantu manusia, namun di sisi lain dapat merusak tatanan kehidupan manusia. Gejala yang secara nyata nampak dialami sebagai pengaruh teknologi adalah hubungan antar sesama manusia semakin jauh, egoisme pribadi semakin berkembang, pengaruh dunia maya terhadap perilaku, mental, dan moral masyarakat semakin meraja lela. Akibat semuanya itu orang kehilangan identitas diri. Identitas merupakan kesadaran akan siapa diri kita dan kesadaran ini akan mempengaruhibagaimana orang menjalani kehidupan, bersikap, bertindak, dan berbicara. (BKSN,2020:61).

Atas dasar itu pula Gereja Katolik mengangkat tema:"Mewartakan Kabar Baik Di Tengah Krisis Iman dan Identitas.” Tema tersebut dijabarkan ke dalam beberapa subtema untuk melihat kebenaran tentang Allah dan identitas orang beriman di hadapan-Nya. Subtema-subtema tersebut didalami selama 4 (empat) minggu dalam bulan September 2020, yaitu: (1) Allah adalah Kasih diambul dari teks kitab suci yaitu 1Yoh.4:7-21; (2)Yesus Anak Manusia dari teks Injil Mat.25:31-46. (3) Orang Berdosa yang Dipercaya oleh Tuhan dari Injil Lukas.:1-11. (4) Persekutuan Orang Beriman diambil dari Ki.2:3747. (BKSN,2020:36-37).

Salah satu kegiatan yang dilaksanakan umat katolik dalam rangka bulan Kitab Suci Nasional Tahun 2020, pendalaman kitab suci. Sebagaimana umat katolik pada umumnya baik di Kring, Lingkungan maupun Paroki secara kumunal mendalami kitab suci dalam bulan September, anak asrama binaan Emaus sebagai komunitas beriman juga melakukan kegiatan yang sama.

Anak asrama binaan Emaus adalah anak-anak yang menempuh pendidikan di beberapa sekolah baik SMP maupun SMA di kota Nanga Pinoh. Mereka tinggal di Rumah Pembinaan Emaus KM.4 Nanga Pinoh. Di tempat ini mereka mendapat pembinaan baik mental maupun spiritual, dilatih berbagai keterampilan fisik maupun kecakapan hidup untuk dapat hidup mandiri. Anak-anak yang tinggal di Rumah Pembinaan Emaus berjumlah32 orang sebagaimana tampak pada tabel 1 berikut: 
Tabel 1. Data Jumlah Anak Binaan

\begin{tabular}{|c|c|c|c|c|}
\hline No & SEKOLAH & $\mathrm{L}$ & $\mathrm{P}$ & $\mathrm{J}$ \\
\hline 1 & SMP & 6 & 7 & 13 \\
\hline \multirow[t]{2}{*}{2} & SMA & 8 & 11 & 19 \\
\hline & TOTAL & 14 & 18 & 32 \\
\hline
\end{tabular}

Data jumlah anak asramabinaan Emaus sebagaimana disajikan pada tabel 1 di atas adalah anak-anak kampung yang berasal dari beberapa desa di Kabupaten Melawi. Sebagai anak yang berasal dari kampung dan tinggal di kota tentu rasa kepercayaan diri dan keberanian untuk menyatakan pendapat sangat kurang. Situasi ini dipengaruhi karena kebanyakan mereka adalah berasal dari orang tua atau keluarga yang tidak mampu dari segi ekonomi, sehingga mereka dibantu beasiswa dari segi pembiayaan pendidikan.

Berdasarkan paparan di atas dapat dirumuskan masalah sebagai berikut:' Apakah Katekese pendalaman kitab suci dapat meningkatkan kepercayaan diri dan keberanian untuk mengungkapkan pengalaman iman anak asrama binaan Emaus?'

Tujuan kegiatan pengabdian ini adalah pendalaman kitab suci untuk mengenalkan kitab suci sebagai sumber iman dan inspirasi hidup. Secara khusus tujuan kegiatan pendalaman ini adalah meningkatkan rasa percaya diri dan keberanian anak asrama binaan Emaus dalam berketekese, mengungkapkan pengalaman iman mereka berdasarkan kitab suci.

Agar anak asrama binaan memiliki pengetahuan dan pemahaman tentang kitab suci serta mencitainya dalam kehidupan sehari-hari, mereka ditugasi untukmembaca teks Kisah Para Rasul, yang dijadwalkan setiap hari satu bab selama bulan September, dari bab 1 sampai bab 28.

\section{METODE PELAKSANAAN}

Metode pendalaman kitab suci dalam rangka Bulan Kitab Suci Nasional Tahun 2020 adalah katekese umat. Metode katekese umat yaitu musyawarah iman, yang merupakan inkulturasi dari budaya musyawarah. Katekese umat adalah dari, oleh dan untuk umat atau dengan kata lain katekese itu sebagai komunikasi iman umat berdasarkan pada situasi konkrit umat menurut pola hidup Yesus Kristus yang bersumber pada kitab suci.

Pada model katekese pendalaman kitab suci ini prosedur yang dilaksanakan adalah: Pertama, Pembukaan yang meliputi: (1) Lagu Pembukaan; (2) Tanda Salib dan Salam, (3) Pengantar Tema, dan (4) Doa Pembukaan. 
Tahap kedua adalah Pendalaman Kitab Suci, yang meliputi : (1) Pembacaan teks Kitab Suci, (2) Pendalaman Iman, (3) Penjelasan dan peneguhan; (4) Pesan dan Penerapan, (5) Doa Umat.

Kemudian bagian terakhir adalah Penutup, yang meliputi : (1) Doa Penutup, (2) Tanda Salib, (3) Lagu Penutup.

Katekese pendalaman kitab suci yang dilaksanakan setiap kali pertemuan menggunakan langkah-langkah yang sama sebagaimana prosedur di atas. Dalam proses ini pembimbing berperan sebagai fasilitator, pengarah, dan motivator bagi peserta pendalaman agar mereka memiliki rasa percaya diri dan berani mangungkapkan pengalaman iman mereka dan berbagi kepada sesama.

Dalam kegiatan pendalaman ini yang menjadi subyek adalah anak asrama binaan Emaus Km.4 Nanga Pinoh, berjumlah 32 orang terdiri 14 laki-laki dan 18 perempuan. Mereka adalah 13 siswa SMP dan 19 siswa SMA.

Teknik pengumpuan data yang digunakan adalah teknik non-tes dengan observasi langsung. Observasi langsung adalah dimana observer ikut serta dalam kegiatan yang sedang dilakukan. Pada waktu melakukan observasi, observer dapat ikut berpartisipasi atau bisa hanya mengamati saja orang-orang yang sedang melakukan suatu kegiatan tertentu yang diobservasi.

Obyek yang diobservasi dalam kegiatan ini adalah rasa percaya diri dan keberanian anak binaan Emaus dalam mengungkapkan pengalaman iman mereka mengacu pada bahan pendalaman kitab suci. Dari jumlah peserta dianalisis berapa persen (\%) yang telah memilki rasa percaya diri dan keberanianmengungkapkan pengalaman imannya. Data dianalisis menggunakan rumus: $P=\frac{C}{T} \mathrm{x} 100$

$$
\begin{aligned}
& P=\text { Persentase yang dicar } \\
& C=\text { Capaian } \\
& T=\text { Total } \\
& 100=\text { pengalian }
\end{aligned}
$$

Berdasarkan rumusan tersebut yang dicari adalah prosentase jumlah peserta pendalaman yang memiliki rasa percaya diri dan keberanian dalam mengungkapkan pengalaman imannya selama proses kegiatan pendalaman kitab suci.

Agar pendalaman dapat berjalan dengan baik dan lancar, maka pelaksanaan kegiatan dipisah antara siswa SMP dan SMA, serta masing-masing kelompok didampingi oleh satu orang pembimbing yang sekaligus berperan sebagai observer. 


\section{HASIL DAN PEMBAHASAN}

Kegiatan Pengabdian ini dilaksanakan selama 4 (empat) hari yakni satu minggu sekali dalam bulan September 2020 bertempat di Rumah Pembinaan Emaus KM 4 Nanga Pinoh Kabupaten Melawi. Tempat ini disebut rumah pembinaan dimaksudkan untuk membedakan dengan asrama pada umumnya, dimana dalam rumah pembinaan anak-anak binaan, dididik dan dilatih untuk hidup berkomunitas sebagai sebuah keluarga. Anak-anak binaan yang tinggal di Rumah Pembinaan Emaus terdiri dari anak-anak SMP dan SMA yang mempunyai tugas pokok yaitu belajar. Belajar dalam hal ini tidak hanya belajar dalam pengertian sekolah saja tetapi belajar hidup bersama, berbagi, saling memperhatikan, dan peka terhadap lingkungan sekitar. Di samping itu anak-anak binaan dilatih berbagai keterampilan baik, fisik maupun non fisik. Program pembinaan keterampilan di antaranya adalah berkebun, memelihara ayam, ikan dan binatang piaraan lainnya. Selain itu bagi anak-anak putrid dilatih memasak, membuat tahu dan tempe, membuat roti, serta membuat eskrim.

Kegiatan non fisik yang menjadi program pembinaan meliputi, pembinaan kepribadian, latihan memimpin doa/ibadat, pembinaan iman, pendalaman kitab suci, latihan mazmur, latihan koor, dan membaca kitab suci. Semua kegiatan yang dilakukan di Rumah Pembinaan Emaus adalah dalam rangka membekali anak-anak binaan agar mereka memiliki keterampilan untuk hidup (kecakapan hidup) sebagai bekal untuk hidup di masyarakat setelah mereka kembali ke kampong halaman masing-masing.

Salah satu kegiatan yang dilaksanakan dalam rangka bulan Kitab Suci Nasional Tahun 2020 adalah pendalaman kitab suci. Tema nasional bulan kitab suci tahun 2020 adalah : Mewartakan Kabar Baik Di Tengah Krisis Iman dan Identitas.” Tema ini mengangkat pengalaman Bangsa Israel yang mengalami krisis iman dan identitas ketika mereka berada di tempat pembuangan (Babel). Mereka mengalami kriris iman kepada Yahwe, dan identitas mereka sebagai bangsa pilihan. Gereja Katolik secara nasional mengangkat masalah krisis iman dan identitas karena Gereja Ketolik melihat dan mengalami bahwa generasi muda Katolik saat ini mengalami hal yang sama dengan bangsa Israel., yakni mengalami krisis iman dan identitas.

Dengan perkembangan ilmu pengatahuan dan teknologi yang semakin pesat dan canggih dewasa ini disatu sisi sangat membantu manusia, namun di sisi lain dapat merusak kehidupan manusia. Gejala yang secara nyata nampak dialami sebagai pengaruh teknologi adalah hubungan antar sesama manusia semakin jauh, egoisme pribadi semakin 
berkembang, pengaruh dunia maya terhadap perilaku, mental, dan moral masyarakat semakin meraja lela. Akibat semuanya itu orang kehilangan identitas diri. Identitas merupakan kesadaran akan siapa diri kita dan kesadaran ini akan mempengaruhi bagaimana orang menjalani kehidupan, bersikap, bertindak, dan berbicara. (BKSN,2020:61).

Atas dasar itu pula Gereja Katolik mengangkat tema:"Mewartakan Kabar Baik Di Tengah Krisis Iman dan Identitas.” Tema tersebut dijabarkan ke dalam beberapa subtema untuk melihat kebenaran tentang Allah dan identitas orang beriman di hadapan-Nya. Subtema-subtema tersebut didalami selama 4 (empat) minggu dalam bulan September 2020, yaitu: Pertemuan pertama, Allah adalah Kasih (1Yoh.4:7-21). Dalam perikop ini peserta pendalaman diajak untuk melihat bahwa Allah yang kita percayai adalah Kasih dan kita manusia yang dikasihi-Nya. Karena Allah adalah Kasih yang mengasihi kita manusia yang percaya kepada-Nya, maka kita yang dikasihi Allah itu juga harus mengasihi sesama. Dalam pertemuan pertama ini rasa percaya diri dan keberanian peserta untuk berdiskusi dan mengungkapkan pengalaman imannya belum nampak antusias,meskipun sudah mencapai 26\%yang aktif. Pada pertemuan kedua, dengan tema:"Yesus Anak Manusia,: (Mat.25:31-46), di mana dalam perikop ini peserta diajak untuk melihat bahwa Yesus yang kita imani adalah Anak Manusia yang berkuasa atas Kerajaan Surga. Sebagai orang yang percaya kepada-Nya, kita akan melihat bagaimana bersikap sesuai dengan kehendak-Nya. Pada pertemuan kedua ini presentasi jumah peserta yang terlibat aktif meningkat menjadi $51 \%$. Pertemuan ketiga membahas tema :”Orang Berdosa yang Dipercaya oleh Tuhan" (Luk.:1-11). Pada perikop ini peserta diajak untuk belajar dari Petrus, yang mengakui bahwa ia adalah orang yang berdosa, tidak pantas untuk dekat dengan Tuhan. Tetapi Tuhan justru mengutus kita yang berdosa ini untukmengajak sesama agar percaya kepada Tuhan. Dalam proses pendalaman ketiga ini jumlah peserta yang aktif meningkat menjadi $72 \%$. Pada pertemuan terakhir, jumlah peserta yang ektif meningkat manjadi 84\% yakni 27 orang dari 32 anak binaan. Pada pertemuan keempat ini tema:"Persekutuan Orang Beriman," (Ki.2:37-47). Melalui perikop ini peserta diajak untuk menyadari bahwa kita adalah orang yang telah dibaptis dan masukdalam persekutuan orang yang percaya kepada Yesus. Dari sisi kita akan melihat apa yang harus kita lakukann sebagai anggota persekutuan..

Proses pendalaman masing-masing subtema dilakukan dengan metode katekese,yaitu musyawarah iman,yang merupakan inkulturasi dari budaya musyawarah. 
Dalam metode ini masing-masing peserta menyampaikan suatu gagasan, pemikiran, dan pengalaman iman yang terinspirasi dari gagasaan pemikiran dan perikop kitab suci.

Perkembangan hasil pendalaman selama 4 (empat) kali pertemuan dapat dilihat pada tabel 2 berikut ini:

Tabel 2. Persentase Keaktifan Peserta

\begin{tabular}{lllcccc}
\hline No & SEKOLAH & JML & $\%$ & $\%$ & $\%$ & $\%$ \\
& & & P1 & P2 & P3 & P4 \\
\hline 1 & SMP PUTRA & 6 & 33 & 68 & 82 & 83 \\
2 & SMP PUTRI & 7 & 14 & 45 & 72 & 85 \\
3 & SMA PUTRA & 8 & 37 & 52 & 75 & 87 \\
4 & SMA PUTRI & 11 & 18 & 46 & 63 & 82 \\
& RERATA \% & 32 & 26 & 53 & 72 & 84 \\
\hline
\end{tabular}

Berdasarkan tabel 2 di atas, dapat menunjukkan bahwa persentase jumlah peserta pendalaman kitab suci yang aktif meningkat secara signifikan dari pertemuan pertama sampai terakhir. Pada pertemuan pertama hanya $26 \%$ yakni 8 orang dari 32 orang peserta pendalaman kitab suci, yang memiliki rasa percaya diri dan keberanian untuk mensharingkan pengalaman iman mereka. Pada pertemuan kedua jumlah peserta yang terlibat aktif meningkat dari 8 menjadi 17 orang, sehingga mencapai 53\%. Kemudian pada pertemuan ketiga jumlah yang aktif 23 orang sehingga menjadi $72 \%$, dan pada pertemuan terakhir mencapai 84\% yakni 27 dari 32 orang telah aktif, memiliki rasa percaya diri dan keberanian dalam berkatakesedalam rangka pendalaman kitab suci. Gafik peningkatan keaktifan peserta pendalaman disajikan pada gambar diagram dibawah ini.

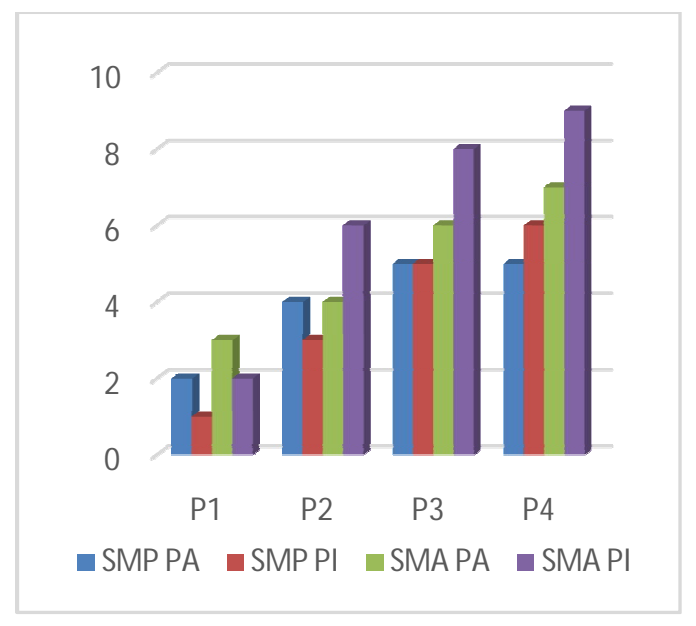

Gambar1. Grafik Peningkatan Aktivitas 
Berdasarkan grafik pada gambar 1, menunjukkan peningkatan jumlah peserta yang aktif berkatekese mengungkapkan pengalaman imannnya meningkat dari pertemuan ke pertemuan berikutnya. Hal ini dapat dilihat pada peningkatan aktivitas masing-masing kelompok sebagai berikut: (1) anak SMP Putra, pertemuan pertama hanya 2 orang yang aktif, pertemuan kedua 4 orang, pertemuan ketiga 5 orang, dan pertemuan keempat 5 orang; (2) anak SMP Putripertemuan pertama yang aktif 1 orang, pertemuan kedua 3 orang, pertemuan ketiga 5 orang, dan pertemuan keempat 7 orang; (3) anak SMA Putra pertemuan pertama yang aktif 3 orang, pertemuan kedua 4 orang, pertemuan ketiga 6 orang, dan pertemuan keempat 7 orang; (4)anak SMA Putri pertemuan pertama yang aktif 2 orang, pertemuan kedua 6 orang, pertemuan ketiga 8 orang, dan pertemuan keempat 9 orang.

Untuk lebih melengkapi pengetahuan dan pemahaman tentang kitab suci maka anak-anak binaan ditugasi untuk membaca Kitab Suci yakni bagian Kisah Para Rasul. Bagian ini terdiri dari 28 bab, dan secara individu anak-anak binaan membaca teks kitab suci 1 (satu) bab sehari. Tujuan membaca teks kitab suci satu bab sehari adalah agar anakanak binaan terbiasa membaca kitab suci dan mencintai kitab suci. Untuk mengevalusi kegiatan membaca kitab suci, serta mengukur pemahaman anak-anak tentang teks kitab suci yang dibaca, maka pada akhir bulan September 2020 diadakan cerdas cermat kitab suci. Dari kegiatan ini hasil evaluasi menunjukkan 65\% materi kitab suci bagian Kisah Para Rasul telah dikuasai anak. Meskipun hasil pemahami belum memenuhi harapan, namun $100 \%$ anak binaan Emaus telah menyelesaikan kegiatan membaca Kisah Para Rasul pada awalminggu keempat bulan Semtember 2020.

\section{SIMPULAN}

Berdasarkan paran di atas dapat disimpulkan bahwa katekese pendalaman kitab suci dapat menumbuhkan kepercayaan diri dan keberanian anak untuk mengungkapkan pengalaman iman mereka. Hal ini ditunjukkan dengan bertambahnya presentase jumlah peserta pendalaman yang aktif berkatekese mengungkapkan pengalaman imannya. Pada pertemuan pertama $26 \%$ yang aktif, pertemuan kedua 53\%, pertemuan ketiga $72 \%$, dan pertemuan keempat $84 \%$

Dengan demikian metode katekese efektif digunakan untuk menumbuhkan rasa peraya diri dan keberanian anak-anak binaan Emaus dalam mengungkapkan pengalaman iman mereka. Ungkapan pengalaman iman hasil pendalaman tersebut mereka wujudkan 
dalam bentuk aksi yang dilaksanakan dalam kehidupan sehari hari, seperti hidup saling mengasihi, saling memperhatikan, dan peka terhadap lingkungan. Di samping itu kegiatan pendalaman kitab suci, khususnya pada kegiatan membaca kita suci teks Kisah Para Rasul, dapat meningkatkan pengetahuan dan pemahaman serta menumbuhkan kecintaan anak-anak binaan Emaus terhadap kitab suci.

\section{UCAPAN TERIMA KASIH}

Dengan terlaksananya kegiatan pengabdian dalam rangka Bulan Kitab Suci Nasional di Kompleks Rumah Binaan Emaus,penulis ucapkan terima kasih kepada:

1. Pastor Agustinus Ubin, CM, yang telah memberi kesempatan kepada kami untuk mengadakan pengabdian dengan subyek anak-anak asrama binaan Emaus.

2. Pastor Sugiono, CM, yang telah memberi pengarahan kepada kami dalam melaksanakan proses pendalaman kitab suci dari awal sampai akhir kegiatan pengabdian.

3. Semuaanak asrama binaan Emaus yang telah berpartisifasi aktif dalam kegiatankegiatan yang dilaksanakan dari pertemuan pertama sampai pertemuan terakhir.

4. Ketua STKIP Melawi yang telah memberi kesempatan kepada kami untuk mengadakan pengabdian di Rumah Pembinaan Emaus.

5. Ketua Unit Penelitian dan Pengabdian Kepada Masyarakat(UPPM) yang telah memberi dukungan kepada kami.

\section{DAFTAR PUSTAKA}

BKSN.2020.Mewartakan Kabar Baik Di Tengah Krisis Iman dan Identitas. LBI : Jakarta Komisi Kateketik KWI. (2019). Katekese Di Era Digital: Kanisiua Yogyakarta KWI. (1996). ImanKatolik;BukuinformasidanReferensi, Kanisius :Yogyakarta Lalu Yosef .Rm. (2007).Katekese Umat. Kanisuus: Yogyakarta

Lembaga Alkibat Indonesia 2000, Alkitab. LBI :Jakarta 